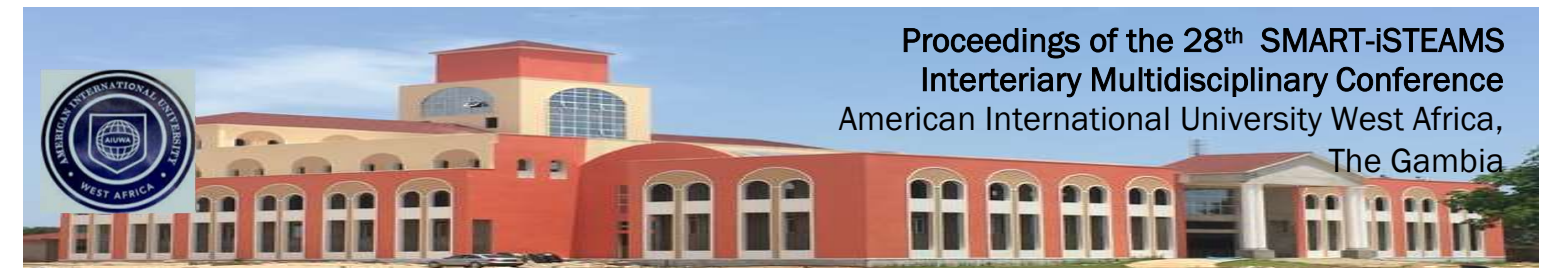

Full Research Paper

\title{
Academic Mentoring As Determinant For Academic Competence Among Teaching Staff In Lagos State Polytechnic, Ikorodu, Lagos, Nigeria
}

\author{
${ }^{1}$ Alasiri, W. A. \\ 2Adewumi, D.O. \\ 3Jelili, S.T. \\ ${ }^{4}$ Longe, $0 . B$

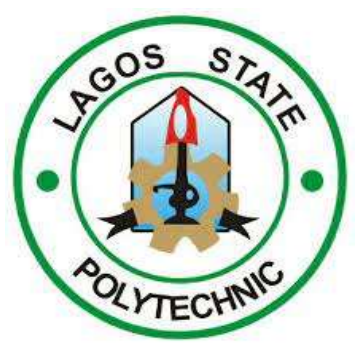 \\ 1,3Department of Marketing \\ Lagos State Polytechnic, \\ Ikorodu, Lagos, Nigeria \\ 2Office Technology and \\ Management Department \\ Lagos State Polytechnic, \\ Ikorodu, Lagos, Nigeria \\ ${ }^{4}$ Academic City University \\ College, Accra Ghana
}

E-mail:

alasiriwaid@gmail.com adewumi_damisola2000@g mail.com

Olumide.longe@acity.edu.gh

Phone

+2348067394544

\begin{abstract}
Research studies have shown that most young and inexperienced academic members in higher institutions all over the world especially in developing nations required assistance in developing their academic career and enhancing their teaching experiences through mentoring. However, academic mentoring has not been effective in many higher institutions of learning, especially those in the developing world, Nigeria not exempted. With quantitative and qualitative approaches, this study explored mentoring among teaching staff, looking at how both variables determine the academic competence of teaching staff in Lagos State Polytechnic, Ikorodu Lagos. A cross sectional survey of all the schools in Lagos State Polytechnic was carried-out with a sample size of 200. The sampling technique used is purposive sampling. The study used descriptive statistics which include tables, percentages, and graph while Chi-Square was used to analyze the formulated hypothesis. Questionnaire was used as the major research instrument. The data analyzed for this study was from 150 academic staff that their questionnaire were properly filled and submitted and out of this, Chief Lecturers, Principal Lecturers and Senior Lecturers constituted 95 (63\%) respondents, who we referred to as Mentor, and others constituted 55(37\%), who we referred to as Mentee. This study used theories on mentoring, leadership and career development that relate to the study. The paper focused on three main research questions: measuring the level of awareness, mentoring and competence and formation of mentoring among teaching staff of Lagos State Polytechnic, Ikorodu. Findings from this study showed that teaching staff in Lagos State Polytechnic are very much aware of academic mentoring, and they believed that academic mentoring were developed on the basis of familiarity in research interests. It was also discovered from the review of literature that, the unresponsive attitude of some junior teaching staff, the pressure of administrative duties, unavailability of formal mentor/mentee structures were identified barriers to good mentoring skills among mentors and mentees. Based on these findings, the paper recommended among others that the institution should develop staff through policies on mentoring in Lagos State Polytechnic systems, this will serve as an avenue to groom new generation of competent academic staff, who will build responsible future leaders
\end{abstract}

Keywords: Academic mentoring, grooming, academic competence, teaching staff

Proceedings Reference Format

Alasiri, W. A., Adewumi, D.O., Jelili, S.T. \& Longe, O.B (2021): Academic Mentoring As Determinant For Academic Competence Among Teaching Staff In Lagos State Polytechnic, Ikorodu, Lagos, Nigeria. Proceedings of the 28th iSTEAMS Intertertiary Multidisciplinary Conference. American International University West Africa, The Gambia. October, 2021. Pp 185-204. www.isteams.net/gambia2021.

DOI - https://doi.org/ 10.22624/AIMS/iSTEAMS-2021/V28P16 


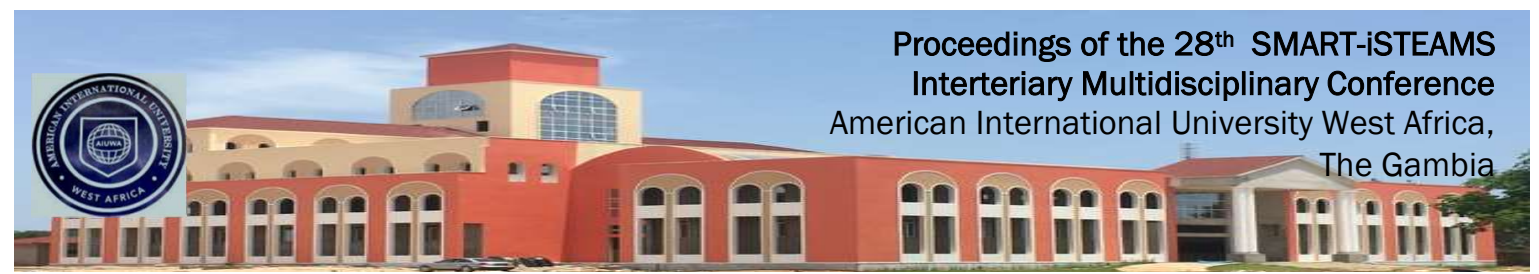

\section{INTRODUCTION}

A higher education institution has been defined as a community of scholars, not excluding other stakeholders, who work together to achieve the goals of the Institution. As a results of current global highly competitive environment in higher education institution ranking by the extent of valuable research and teaching competency, the mode of operation of Higher Institution of learning has no doubt been greatly influenced. Parents and students who serves as the key actors in higher institution services prefer Institution that is able to portray high quality teaching and learning skills. Higher institutions now deemed it fit to engage their human capital in mentoring and grooming processes (Abugre \& Kpinpuo, 2017).

To meet the global competitive challenges higher institutions of learning have come under intense pressure to create a kind of competitive advantage (Maringe \& Gibbs, 2008). These challenges would place the institutions in a position to attract greater funding opportunities, admit good students, and attain strong research capacity and capability (Archer, 2008). Achieving these academic excellence, the roles of mentoring and grooming can never be overemphasized as, this serves as the building blocks for any human resource development effort within an institution (Bozeman \& Feeney, 2007).

Mentorship is a relationship where an experienced person invests his or her time and expertise to help a younger person achieve a pre-defined goal. Mentoring is not a new phenomenon, the concept mentoring is drawn from Homer's Odyssey in Ancient Greek times. The character Alcimus was travelling and entrusted his son, Telemachus, under the care of the character named Mentor, to guide him in his time of difficulty. Thus, Mentor's role was to be a father figure to the mentee (Telemachus) and to give specific advice in terms of growth according to an agreed goal between them. Most organizations use mentoring either formally and or informally as a career-development strategy where experienced executives offer developmental assistance to their less experienced members of staff.

The greatness of higher educational institutions will indeed be determined by effective academic mentoring strategies put in place. Extant literature have identified three main academics mentoring strategies based on the mentoring relationship between experienced academic staff, usually an older and experienced academic staff, serving as guide, role model or teacher to inexperienced or junior academic staff (Johnson, 2002). Mentoring relations can also be between academic colleagues according to Bouwma- Gearhart (2012). Higher institution of learning can also provide mentoring relations between the academic staff this will in a way serve as career support programs (Parker, Authur, \& Inkson, 2004).

Despite the importance of academic mentoring in attaining academic competence, the concept has received little or no attention among academic staff of higher institution of learinng. Researches have shown that the concept of academic mentoring and grooming were not very cleared to the academic staff as there are little or no consensus on the exact meaning of mentoring and grooming as confirmed by Koki (1997). Furthermore, there are no clear terms of the actual role mentors and mentee play on mentoring processes, what distinguishes mentoring from other forms of academic support programme, and even how the mentoring process is managed (Cullingford, 2016; Rebecca, 2016; Martin, 2006). It is this gap that our study intends to fill; to investigate academic mentoring as 


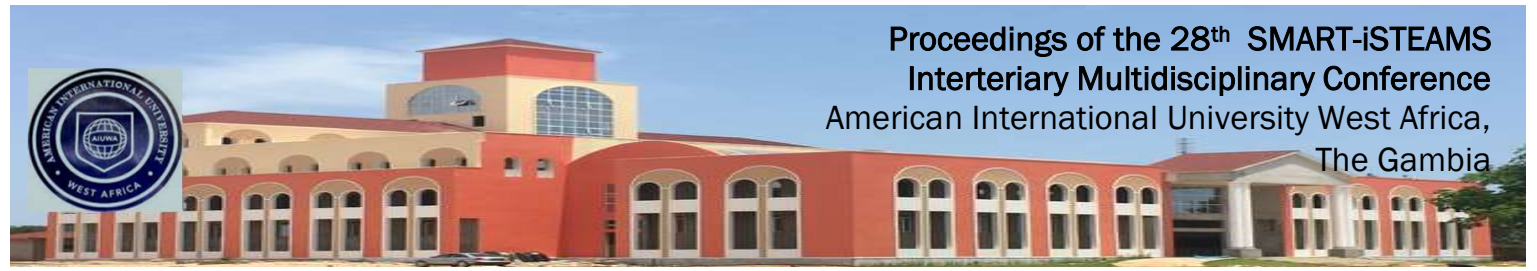

it enhances the academic competence of teaching staff in higher institution of learning, using Lagos State Polytechnic, Ikorodu as a study.

The objectives in this study are:

$>$ To investigate on the level of awareness of academic mentoring and academic grooming among academic staff of Lagos State Polytechnic, Ikorodu.

$>$ to measure the significant values academic mentoring play in improving academic competence of mentors and mentee in Lagos State Polytechnic

$>$ To know if Lagos State Polytechnic teaching staff engage in formal and or Informal mentoring.

This study is guided by three research questions and one hypothesis:

RQ1: What is the level of awareness of staff on academic mentoring in Lagos State Polytechnic?

RQ2: How will mentoring improve academic competence of teaching staff?

RQ3: What is the form of mentoring adopted among academic staff of Lagos State Polytechnic?

The only hypothesis stated in the null form is: Academic mentoring is not a determining factor to achieving academic competence in Lagos State Polytechnic, Ikorodu This study is structured as follows; Section one is the introductory aspect of the paper, Section two discussed the review of relevant literature while section three is devoted to the method adopted in the study. Section four contained the results of discussion and section five is the conclusion and recommendation.

\section{REVIEW OF LITERATURE}

\subsection{Conceptual Review on Mentoring and Academic Competence}

Mentoring is a method of growing in use for establishing relationship between junior and senior employees, a method gaining popularity in facilitating both employee and management development in the organization (Russel, 2004). Mentoring can be a powerful human resource development and empowerment tool for the transmission of knowledge and skills in a supportive environment (Ilesanmi, 2011).

It is a process in which mature and experienced staff serving as mentors share their wisdom, skills, knowledge, values and experiences with younger employees (or potential employees) on a one-on-one basis in order to develop the skill of their mentees. Anderson and Shannon, as quoted by Abiddin and Hassan (2012), aptly defined mentoring as nurturing in which a more skilled or more experienced person, serving as a role model, teaches, sponsors, encourages, counsels, and befriends a less skilled or less experienced person for the purpose of promoting the latter's professional and/or personal development. Mentoring functions are caring relationship between the mentor and the mentee. Mentoring has been viewed as a powerful means of enhancing the professional success and personal well-being of academic members in institution of higher learning, particularly among early-career members and junior academic staff ( Zambrana, Espino, Castro, Cohen, \& Eliason, (2015). Academic mentoring usually is regarded as the task of an experienced lecturer to introduce a young lecturer in his/her early lecturing career.

Kirigha and Neema- Abooki (2008) as quoted by Rosemary and Millie (2015) academic mentoring in higher education is an innovation to empower and improve quality of teaching. Landolt (2012); Masehela and Ndebele (2006) defined mentoring as an informal face-to face communication process, over a predetermined and sustained period of time, between a person who is perceived to have greater 


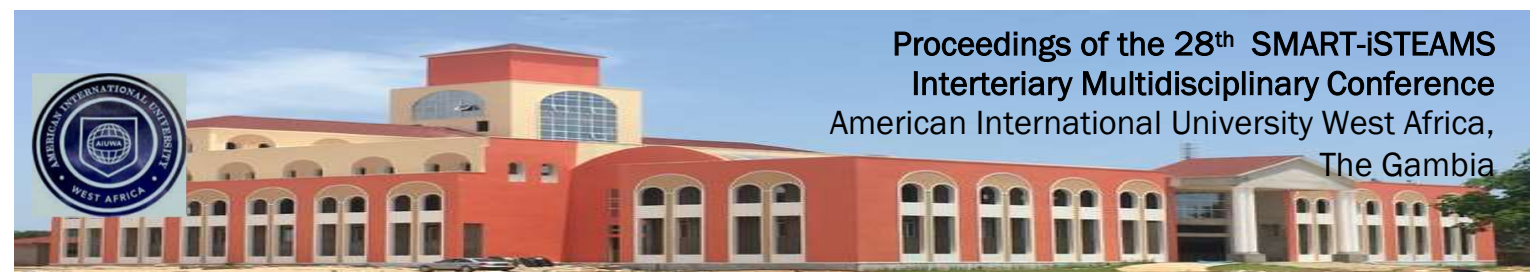

relevant knowledge, wisdom, or experience (the mentor) and a person who is perceived to be less knowledgeable (mentee). In addition, a mentor is knowledgeable in a specific academic area of expertise and should share that knowledge and skills with their mentees (Landolt, 2012). It is further argued that effective mentoring is more than a question-and-answer session, but involves various informal methods of sharing information through dialogue, and the development of an ongoing relationship of open learning where the mentor and the mentee face and resolve challenges as a team.

Mentoring relationship involves exchange of wisdom, learning and development of skills and knowledge about the organization for the protégé's career growth (Akinbobola, 2013). Noe (1988) and Kram (1983) identified two major dimensions of the mentoring relationship which are career support and psychosocial support functions. Career support function include sponsorship, coaching, exposure to important contacts and resources, visibility, facilitating protection of the mentee and assignment of challenging work to enhance the protégé's career. Psychosocial support functions embrace the role modelling, friendship, counselling, acceptance, and confirmation of the mentee (Clutterbuck, 2004; Kram 1983).

Knowledge transfer according to DeLong (2004) is a key mechanism for organizations success. Similarly Von Krogh (2000) emphasizes the importance of knowledge sharing, while Becerra Fernandez and Sabherwal (2001) found that social processes played an important role in the transfer of tacit knowledge among members in an organization. According to Nonaka and Takeuchi (2001) workplace relationships such as mentoring should be fostered to promote transfer of tacit knowledge. Wright (2003) stresses the importance of human resource development to organization success. Mentorship is such a factor in that it promotes guidance on career development and role modelling which both contribute greatly to employee's development.

While citing Kram (1985) Ojedokun (2011) saw mentoring as helping the protégées work out personal problems and thereby enhancing the protégées' self-image. The existence of interpersonal bond that fosters mutual trust enables the protégées to identify with their mentors to offer their support and counsel needed. The mentor applies active listening and rapport skills that enables both individuals to address their concerns. The mentor reinforces with the protége that both of them are highly valued employees and contributors to their organization. Langhout, Rhodes and Osborne (2004) identified four styles of mentors: moderate mentors which provides mentees with conditional support and moderate levels of structure and activities; unconditionally supportive mentors provides highest level of support with moderate levels of structure and activity; active mentors gives highest level of activity combined with the lowest degree of structure and low-key mentors is endowed with highest support and lowest activity. Leidenfrost, Strassing, Schabmann, Carbon and Spiel (2011) added three more peer-mentoring styles, namely the motivating master mentoring, informatory standard mentoring and negative minimalist mentoring.

\subsection{Theoretical Framework}

Super's Career Development Theory

One of Donald Super's greatest contributions to career development has been his emphasis on the importance of the development of self-concept. According to Super, self-concept changes over time and develops as a result of experience and information. As such, career development is lifelong. Super developed the theory and work of colleague Eli Ginzberg. Super felt that Ginzberg's work had weaknesses, which he wanted to address. Super extended Ginzberg's work on life and career 


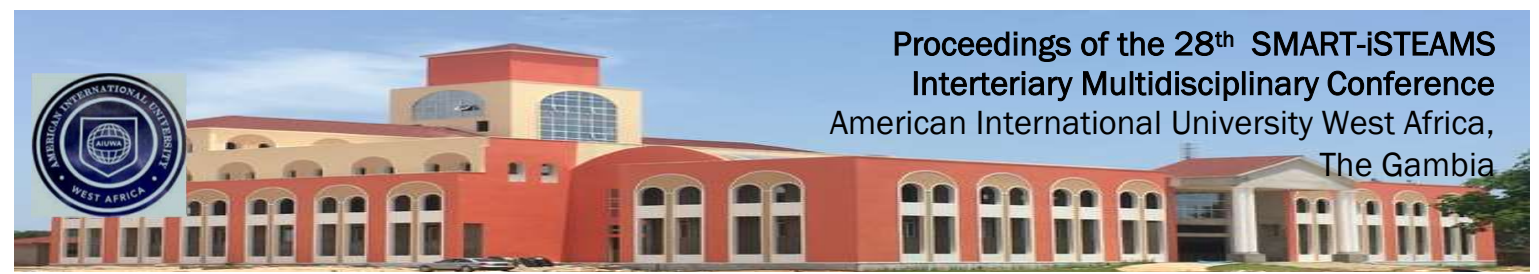

development stages from three to five, and included different sub-stages. Super's theory did not arise at one time and stop there, but it developed itself over a long period of time. Different constructs were added, and adjustments were made since 1953 until the 1990's.

Career development and self-concept were core concepts in Super's theory. Career Development Theory was an elaboration of Ginzberg's assumptions as indicated above, but also included many other theorists' ideas, such as those of Thorndike, Hull, Bandura, Freud, Jung, Adler, Murray, Maslow, Allport and Rogers. From all these theorists' work, Super, developed a comprehensive theory that covered many aspects of life. Super's theory sees career choice as a life-long process that happens throughout someone's life, from childhood to adulthood Career development based on matching the individuals' abilities and interests with the work, and is influenced by economic, social, environmental and physical factors according to super theory. Changes in these factors may have an impact on individuals' career choice. Super's theory is comprised of different developmental stages during which career progression is made. During these developmental stages, the individual develops skills , gathered information and acquires a level of maturity to adopt in his or her career choice.

\subsection{Empirical review}

In a study by Eisenberger, Steelhammer, Vandenberghe, Sucharski, and Rhoades (2002) to investigate the link between employees' perceived organizational support, superior support, and employee turnover, they established that supervisors contribute to perceived organizational support and ultimately to job retention, In addition, employees' perception of good support from their institutions strengthened their commitment, citizenship behavior, retention, and consequently, their performance through a social exchange or a reciprocal process. Other studies have also revealed that when organizations are perceived by workers to be supportive, encouraging and empowering management (Kanter 2003), trust develops among co-workers (Ferres et al., 2004), and ultimately career and mentorship support is improved within the organization. Thus, building relationships with co-workers in the form of mentoring support creates more opportunities for social and inter-cultural contact, and increases knowledge sharing among staff.

\subsection{Mentoring and Academic Competence}

Mentoring relationship can be viewed from different perspectives, not only the potential benefit to the young teacher, but also the professional development of the experienced teacher has to be taken into account. Mentoring could empower the continuous and lifelong development of teachers. The learning partnership of the two persons embodies a considerable advantage to promote a single school's culture as well as the personal and professional growth (Dietlind \& Lydia Van Andel, 2002).

Mentoring is interpreted differently in different contexts. Du Preez et al. (2013) defined peer mentoring within the academic context (module mentoring) as a process whereby reciprocity and equal status abide, and both the mentor and the mentee exchange knowledge, ideas, support and interest to the benefit of both parties. These authors advance the importance of reciprocity and equality between the mentor and mentees since in this context they both occupy the same position, that of student. In that sense, they both stand a chance of learning something from each other or from the interaction itself. The motivating master mentor performs well academically, this type of mentors committed to mentoring sessions, and provides informational and motivational mentoring, while avoiding negative mentoring, informational mentors focus on providing information, hence the mentee font even ask for such information, while negative minimalist mentors are ignorant of the content and fail to answer any questions during the course of mentoring. 


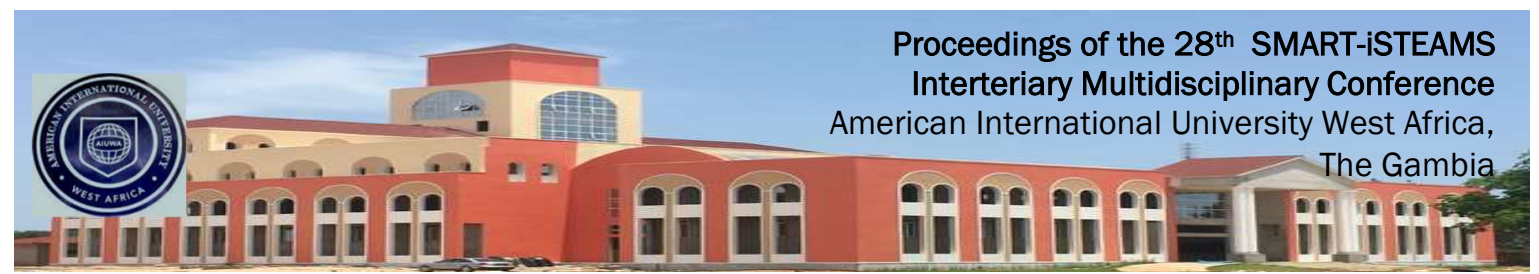

Studies suggest that mentoring leads to greater career satisfaction, although mentoring will not alone solve the school or faculty retention problems. Mentoring can foster an environment of collegiality and a sense of belonging, both of which contribute to productivity and ease the process of socialization for pre-tenure faculty. Mentors can integrate mentees into professional circles and provide opportunities for career advancement. Mentoring has been associated also with improved teaching evaluations. In focus-group discussions, and their ability to negotiate the demands of teaching, research, and service. Good mentoring can create an avenue that promotes trust and respect between junior and senior academics. As a contributing factor in professional development mentoring can establish new relationships for research and publishing opportunities. For example, Few, Piercy and Stremmel, in press A mentoring program can help to establish standards of excellence for the department. It can foster and support change within departments and within the broader community. Mentoring can also be a source of personal satisfaction for mentors.

Psychoanalyst Erik Erikson and psychologist Levinson, who have traced the stages of a man's life, found that mentoring fulfills an important function at a particular point in the life cycle. During the stage of generativity, when individuals turn from personal development and family life to concern with making the world a better place for other young adults, mentoring a junior colleague can help to accomplish this important life task. Benefits to mentors are not necessarily self-evident, however, to encourage faculty to undertake mentoring activities, both the college and the departments must find ways to convey the benefits of mentoring to potential mentors and to reward mentors for the time and energy needed to design successful mentoring programs and serve as effective mentors.

In this competitive global environment, higher educational institutions should be about how to maximize staff competencies and skills in order to stay in or ahead of the competition. In higher education, the kinds of talent required to accomplish institutional goals often demand that institution provide various staff career support services such as workshops, seminars, educational support packages, and other relevant courses. Such "moral support for and opportunities to invest in one's career" (Kuijpers, Schyns, \& Sheerens, 2006) would impact on both individual and organizational growth.

\section{METHODS}

This study adopted quantitative and qualitative approach, by exploring mentoring, looking at how mentoring determines the academic competence of teaching staff in Lagos State Polytechnic, Ikorodu Lagos. A cross sectional survey of all the 367 academic staff in all the 7 schools in Lagos State Polytechnic was carried-out with a sample size of 200 Lecturers. The sampling technique used is purposive sampling. The study used descriptive statistics which include tables, percentages, and graph while Chi-Square was used to analyze the formulated hypothesis. Questionnaire was used as the major research instruments. The data analyzed for this study was from 150 academic staff that their questionnaire were properly filled and returned; from the respondents, Chief Lecturers, Principal Lecturers and Senior Lecturers constituted 95(63\%) respondents, who we referred to as mentor, and others constituted 55(37\%), who we referred to as mentee. The paper focused on three main constructs, namely, Academic Mentoring, Grooming and Academic Competence among teaching staff of Lagos State Polytechnic, Ikorodu. 


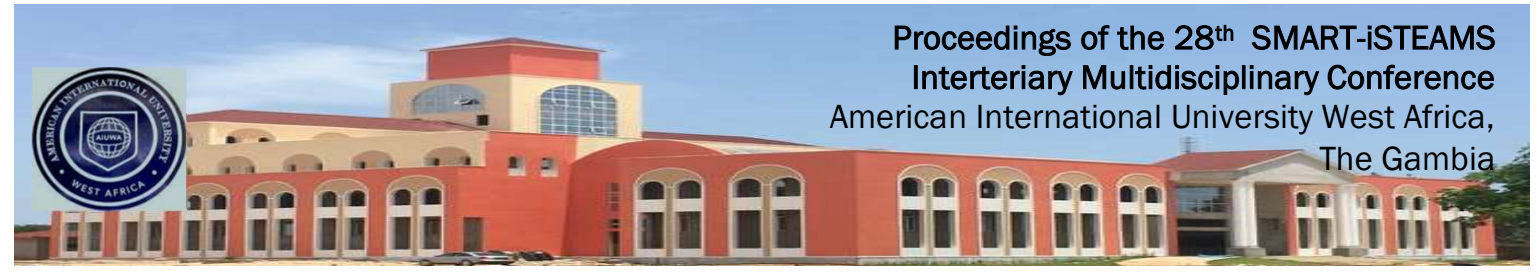

\section{RESULTS AND DISCUSSIONS}

Table 1: Demographic Representation

\begin{tabular}{|l|l|c|}
\hline Gender & Option & Percentage\% \\
\hline Male & 100 & 67 \\
\hline Female & 50 & 33 \\
\hline Total & 150 & 100 \\
\hline
\end{tabular}

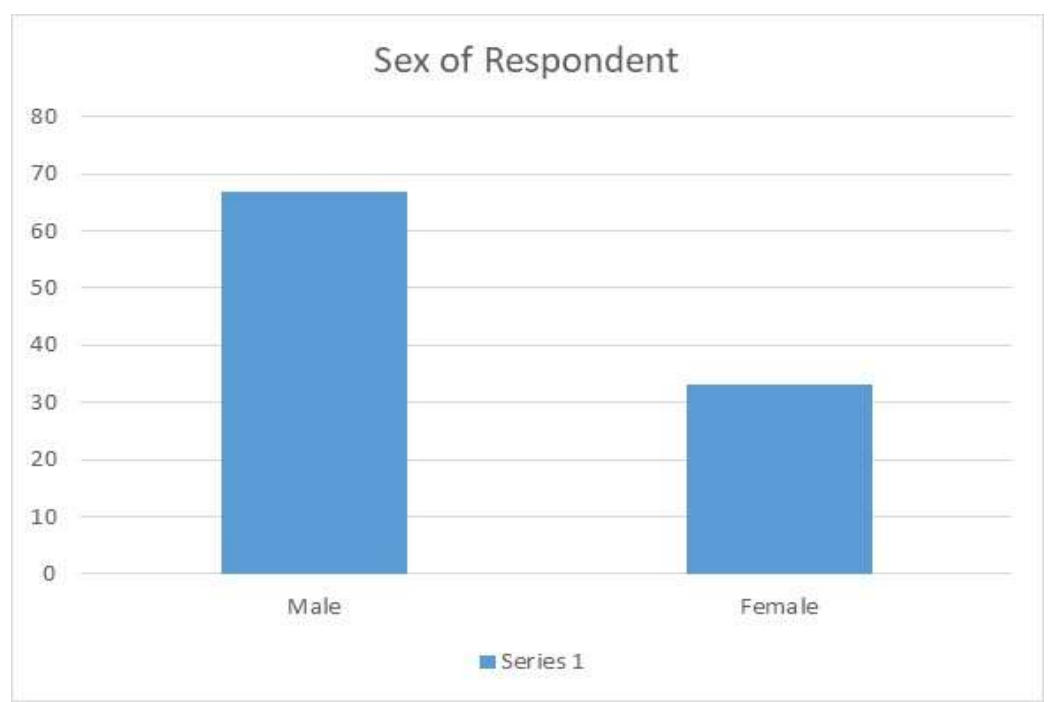

Figure 1: Sex of Respondents

From the above table $1,100(67 \%$ of the respondents were male while $50(33 \%)$ of the respondents were female. This implies that more male took part in the survey than the female.

Table 2: Marital Status of Respondent

\begin{tabular}{|l|l|l|}
\hline Marital Status & Option & $\%$ \\
\hline Married & 120 & 80 \\
\hline Single & 30 & 20 \\
\hline Total & 150 & 100 \\
\hline
\end{tabular}



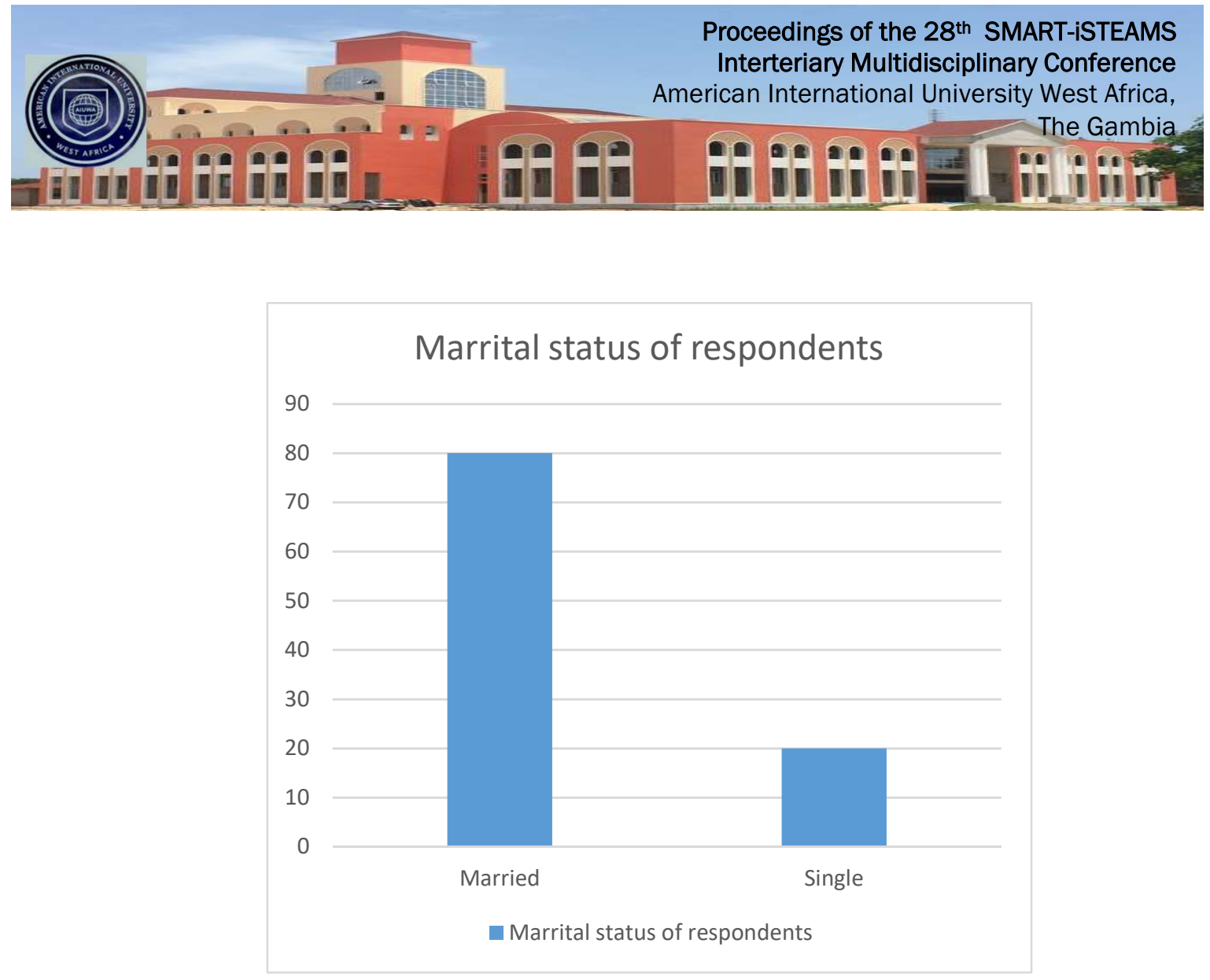

Figure 3: Graphical representation of respondents marital Status

From table 2 above, 120(80\%) of respondents were married, 30(20)\% were single. This portend the level of commitment and responsibilities of people who were surveyed in terms of their marital status.

Table 3: Age Group of Respondents

\begin{tabular}{|l|l|c|}
\hline Age & Option & Percentage\% \\
\hline $21-30$ Years & 10 & 7 \\
\hline $31-40$ Years & 35 & 23 \\
\hline $41-50$ Years & 30 & 20 \\
\hline $51-60$ Years & 52 & 35 \\
\hline 60 and above & 23 & 15 \\
\hline
\end{tabular}



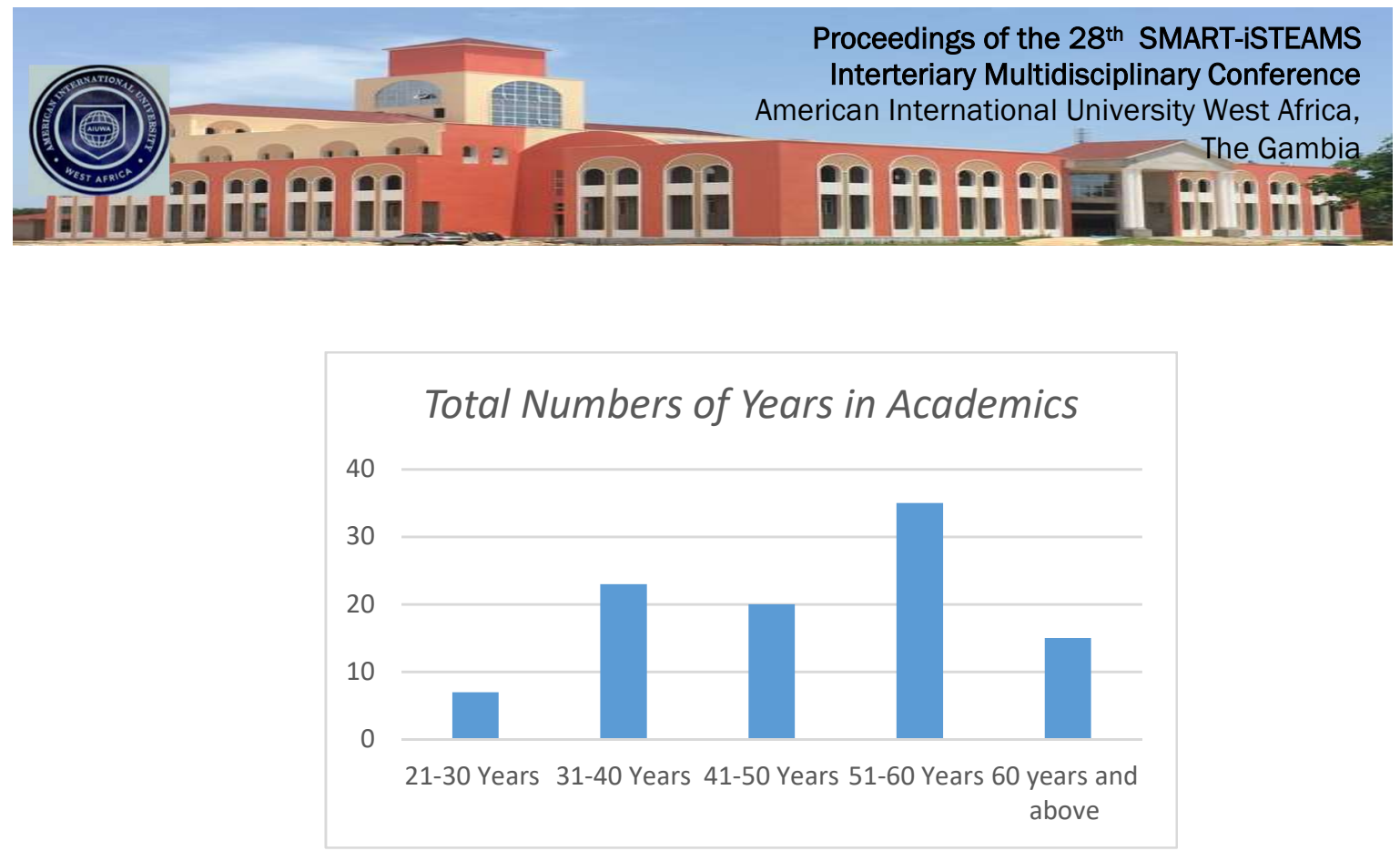

Figure 3: Age group

From Figure 3 above, it shows that respondents between the ages of $21-30$ years were 10(7\%), respondents between the ages 31-40years were 35(23\%), ages $41-50$ are 30 respondents, representing 20\% while ages 51-60 are 52 respondents representing $35 \%$ and ages 61 and above are 23 respondents representing 15\%.This analysis showed that 82(55\%) of the respondents who have put in better part of their lives formed the highest crop of the sampled.

Table 4: Highest Level of Education

\begin{tabular}{|l|l|l|}
\hline Level of Education & Option & Percentage\% \\
\hline Ph.D & 38 & 25 \\
\hline MSc./MBA & 92 & 62 \\
\hline BSc & 15 & 10 \\
\hline HND & 05 & 03 \\
\hline Total & 150 & 100 \\
\hline
\end{tabular}

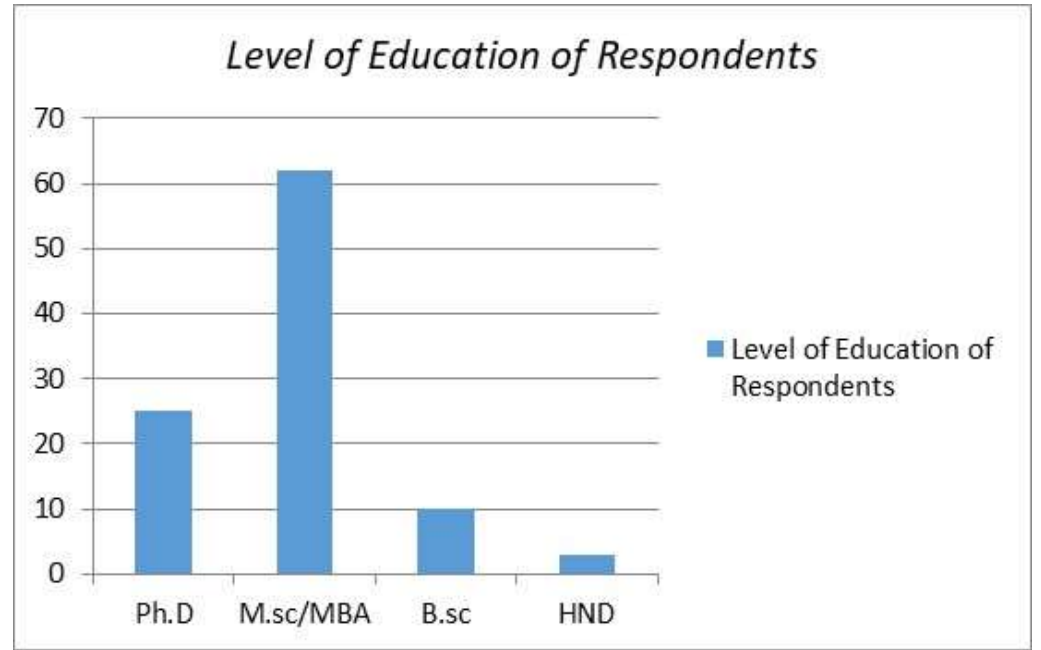

Figure 2: Graphical representation of Respondents level of education 


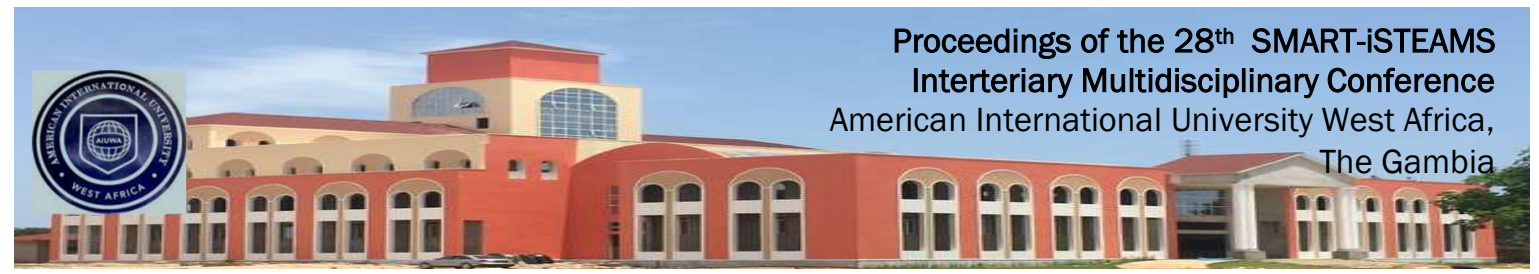

From table 4 above, majority of the surveyed respondents 92(62\%) have MSc as highest academic qualification. Only $38(25 \%)$ of the respondents have $\mathrm{PhD}$ as the highest qualification. This implied that many of the respondents still need to acquire the highest qualification required in academics.

Table 5: Academic Status of Respondents

\begin{tabular}{|l|l|l|}
\hline Academic Status & Option & $\%$ \\
\hline Assistant Lectu $\backslash \mathrm{er}$ & 10 & 7 \\
\hline Lecturer III & 15 & 10 \\
\hline Lecturer II & 10 & 7 \\
\hline +Lecturer I & 20 & 13 \\
\hline Senior Lecturer & 41 & 27 \\
\hline Principal Lecturer & 50 & 33 \\
\hline Chief Lecturer & 04 & 3 \\
\hline Total & 150 & 100 \\
\hline
\end{tabular}

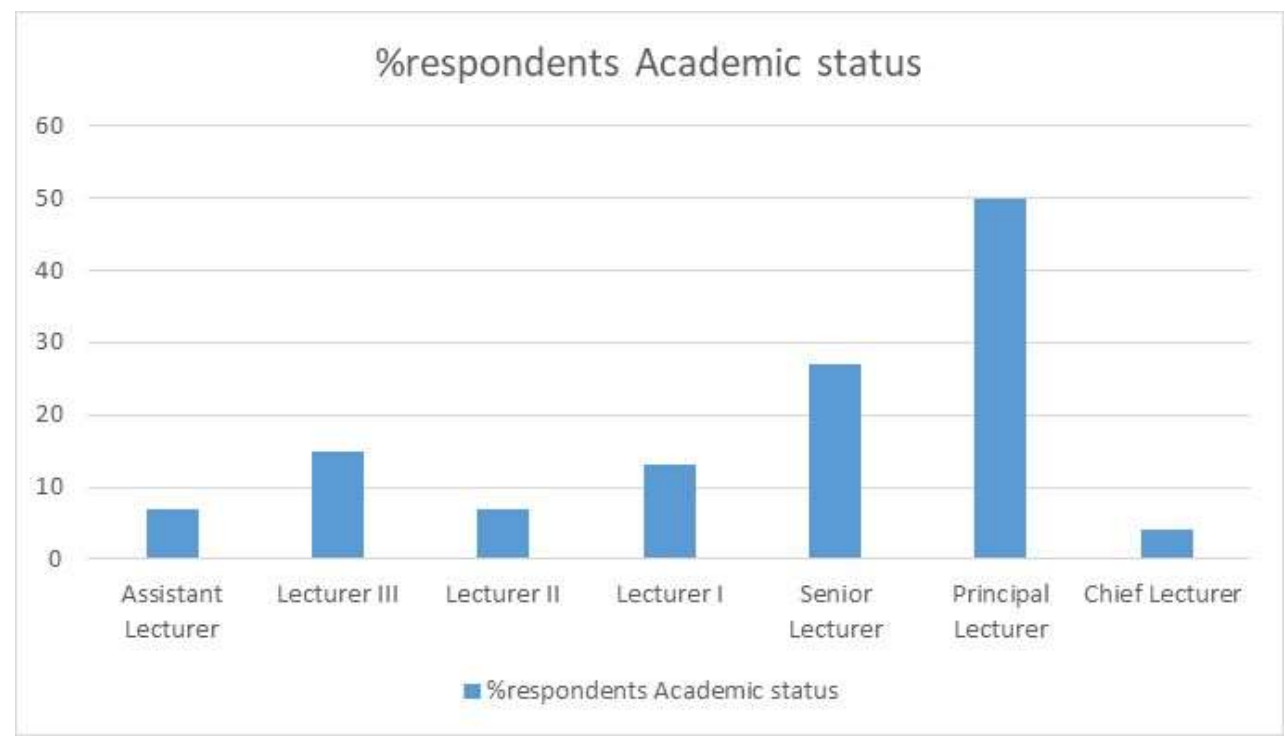

Figure 3: Recommend Academic Status

Table 5 above shows the academic status of the respondents, total number of Assistant Lecturers are 10(07\%), Lecturer III are 15(10\%) respondents. Lecturer II were 10 respondents representing (7\%), Lecturer I 20 respondents representing (13\%). Senior Lecturer were 41 respondents representing (27\%). Principal Lecturer constituted 50(33\%) and Chief Lecturer were 4 (3\%) in the survey. From above, $55(37 \%)$ of the respondents fell into the category of mentees while $95(63 \%)$ belonged to the group of mentors in this study.

RQ1: Level of awareness for academic mentoring in Lagos State Polytechnic, Ikorodu 


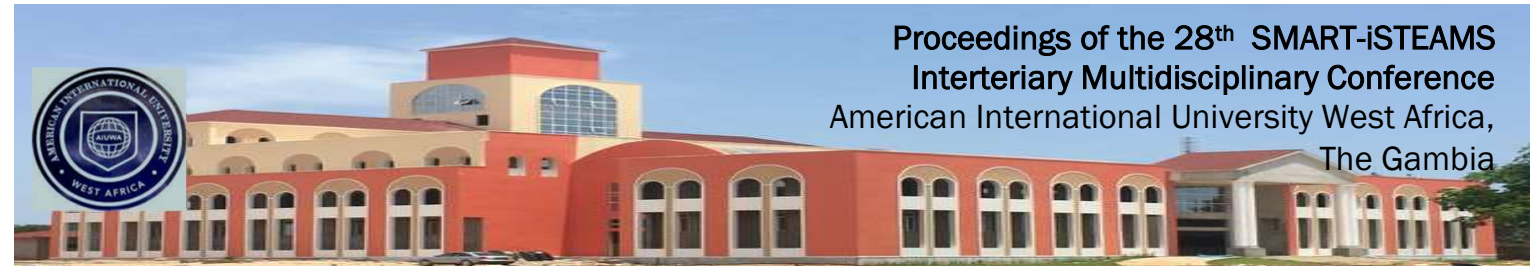

Table 6: Level of awareness for academic mentoring in Lagos State Polytechnic, Ikorodu

\begin{tabular}{|l|l|l|l|l|l|l|l|l|l|}
\hline & \multicolumn{9}{|c|}{ Sources Response Rate } \\
\hline Opinion & Yes & $\%$ & No & $\%$ & Undecided & $\%$ & Total & $\%$ \\
\hline $\begin{array}{l}\text { Are you aware of mentoring in } \\
\text { Academics }\end{array}$ & 150 & 100 & Nil & Nil & Nil & Nil & 150 & 100 \\
\hline $\begin{array}{l}\text { Are you involved in Academic } \\
\text { Mentoring }\end{array}$ & 141 & 94 & 9 & 6 & Nil & Nil & 150 & 100 \\
\hline Do you have a mentor & 55 & 100 & nil & nil & Nil & Nil & 55 & 100 \\
\hline Do you have a mentee & 85 & 90 & 6 & 6 & 4 & 4 & 95 & 100 \\
\hline & & & & & & & & \\
\hline
\end{tabular}

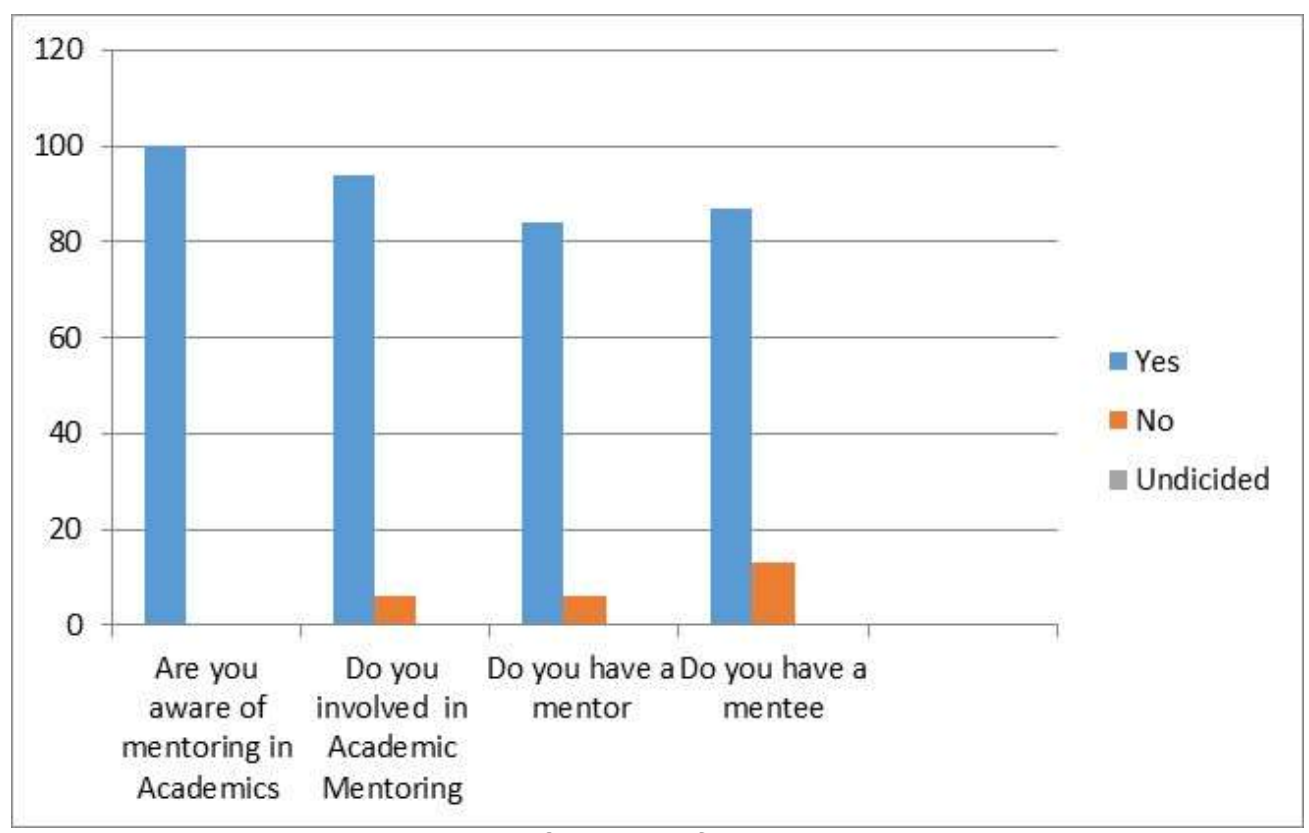

Figure 6: Level of Awareness

Table 6 depicts respondents answers to the research questions one (RQ1):All the respondents $150(100 \%)$ were positive in their replies meaning they were all aware of mentoring in academic setting. A total of 141 (94\%) of the respondents confirmed being involved in academic mentoring; 9 $(6 \%)$ however replied in the negative. All the respondents $55(100 \%)$ categorized as mentees (that is, assistant lecturers to lecturers 1 ) confirmed that they have mentors. On whether the mentors have mentees, $85(90 \%)$ replied in the positive, 6(6\%) replied in the negative while another $6(6 \%)$ could not decide. The above showed a high level awareness of academic mentoring. The mentoring could however be formal and or informal as depicted in the responses by the sample surveyed.

\section{RQ2: Significant Roles Mentoring plays in Improving Academic Competence of Mentor and Mentee in Lagos State Polytechnic, Ikorodu}




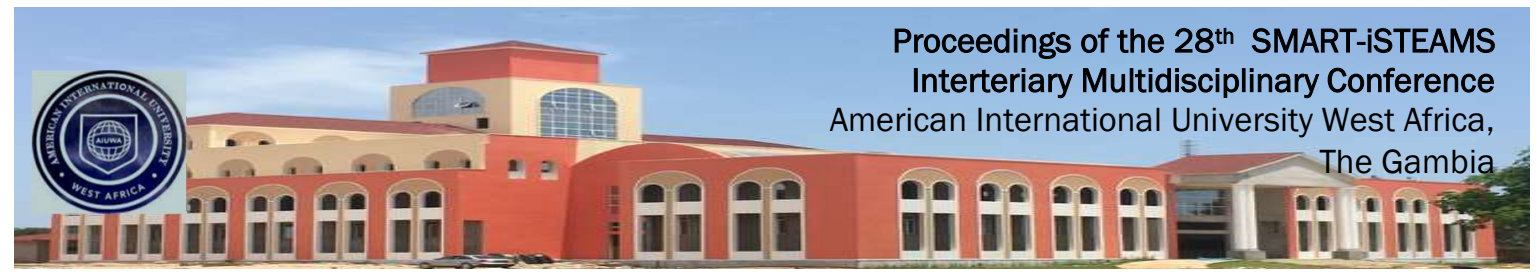

\begin{tabular}{|l|l|l|l|l|l|l|l|l|l|l|}
\hline & \multicolumn{7}{|c|}{ Response Rate } & & & \\
\hline Opinion & SA & $\%$ & A & $\%$ & SD & $\%$ & D & $\%$ & N & $\%$ \\
\hline $\begin{array}{l}\text { Mentoring has positive } \\
\text { effect on Academic } \\
\text { Competence in Lagos } \\
\text { State Polytechnic }\end{array}$ & 98 & 66 & 30 & 20 & 17 & 11 & 5 & 3 & Nil & Nil \\
\hline $\begin{array}{l}\text { Mentoring improves your } \\
\text { academic competency }\end{array}$ & 80 & 53 & 30 & 20 & 10 & 7 & 20 & 13 & 10 & 7 \\
\hline $\begin{array}{l}\text { Mentoring has helped my } \\
\text { teaching ability over the } \\
\text { years }\end{array}$ & 95 & 63 & 55 & 37 & Nil & Nil & Nil & Nil & Nil & Nil \\
\hline $\begin{array}{l}\text { Mentoring has not } \\
\text { improved my lecturing } \\
\text { skills over the years }\end{array}$ & 20 & 13 & 04 & 3 & 120 & 80 & 6 & 4 & Nil & Nil \\
\hline $\begin{array}{l}\text { I gain experiences from } \\
\text { my mentor/mentee } \\
\text { experience over years }\end{array}$ & 120 & 80 & 10 & 7 & 15 & 10 & 5 & 3 & Nil & Nil \\
\hline
\end{tabular}

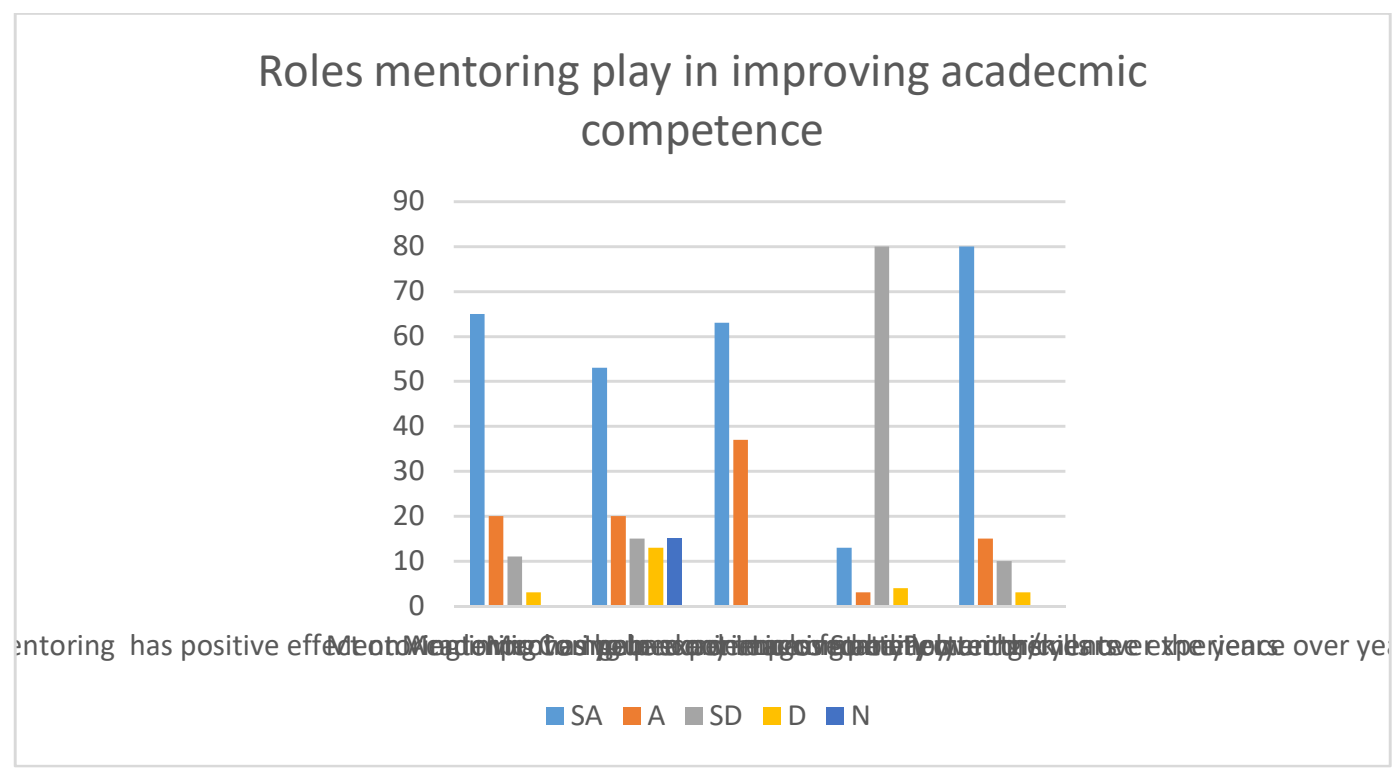

Table 7 above analyses the roles mentoring plays in improving academic competence of mentors and mentees in Lagos State Polytechnic, Ikorodu. 98 respondents representing 66\% strongly agreed that Mentoring has positive effect on Academic Competence in Lagos State Polytechnic, 30 respondents representing 20\% agreed to this opinion, 17 respondents representing $11 \%$ Strongly disagreed while the remaining 5 respondents representing 3\% disagreed to the opinion. When the respondent were 


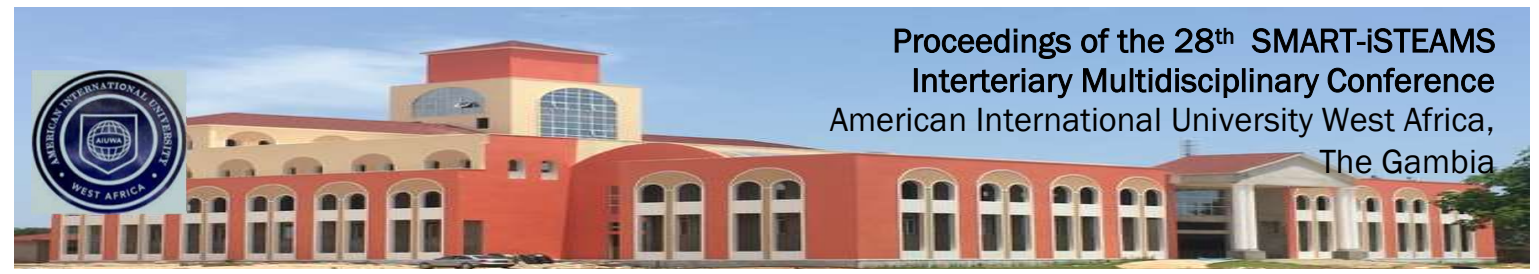

asked if Mentoring improves academic competence in Lagos State Polytechnic, 80 respondent representing 53\% strongly agreed , 30 respondents representing 20\% agreed that mentoring improved academic competence 10 respondents representing 7\% strongly disagreed that mentoring improves academic competence 20 respondents representing 13\% disagreed that mentoring improves academic competence and the remaining 10 respondents representing $7 \%$ were neutral in their responses. With the 98 respondents representing $66 \%$ one may deduce that mentoring has a positive effect on academic competence among teaching staff of Lagos State Polytechnic, Ikorodu.

RQ3: How mentoring relationships were form among Senior and Junior Academics in Lagos State Polytechnic, Ikorodu

Table7: How mentoring relationships were formed among Senior and Junior Academic staff in Lagos State Polytechnic, Ikorodu

\begin{tabular}{|l|l|l|l|l|l|l|l|l|l|l|}
\hline & \multicolumn{7}{|c|}{ Response Rate } & & \\
\hline Option & SA & $\%$ & A & $\%$ & SD & $\%$ & D & $\%$ & N & $\%$ \\
\hline $\begin{array}{l}\text { Mutual respect and } \\
\text { reverence for academic } \\
\text { accomplishments, lead } \\
\text { to share resources and } \\
\text { experience }\end{array}$ & 98 & 66 & 30 & 20 & 17 & 11 & 5 & 3 & Nil & Nil \\
\hline $\begin{array}{l}\text { Joint research, } \\
\text { publications, teaching } \\
\text { and } \\
\text { conference/workshop } \\
\text { attendance lead to } \\
\text { mentee mentor } \\
\text { relationship }\end{array}$ & 100 & 67 & 25 & 16 & 12 & 8 & 10 & 7 & 3 & 2 \\
\hline $\begin{array}{l}\text { Approaching senior } \\
\text { colleagues with } \\
\text { development problems } \\
\text { encourages mentoring in } \\
\text { academic }\end{array}$ & 88 & 59 & 35 & 23 & 20 & 13 & 7 & 5 & Nil & Nil \\
\hline $\begin{array}{l}\text { Provision of academic } \\
\text { leadership by senior } \\
\text { members lead to } \\
\text { mentoring relationships }\end{array}$ & 96 & 64 & 40 & 26 & 10 & 7 & 4 & 3 & Nil & Nil \\
\hline $\begin{array}{l}\text { Members of Academic } \\
\text { can request to be mentor } \\
\text { or mentee of an academic }\end{array}$ & 99 & 66 & 32 & 22 & 5 & 3 & 5 & 3 & 9 & 6 \\
\hline
\end{tabular}



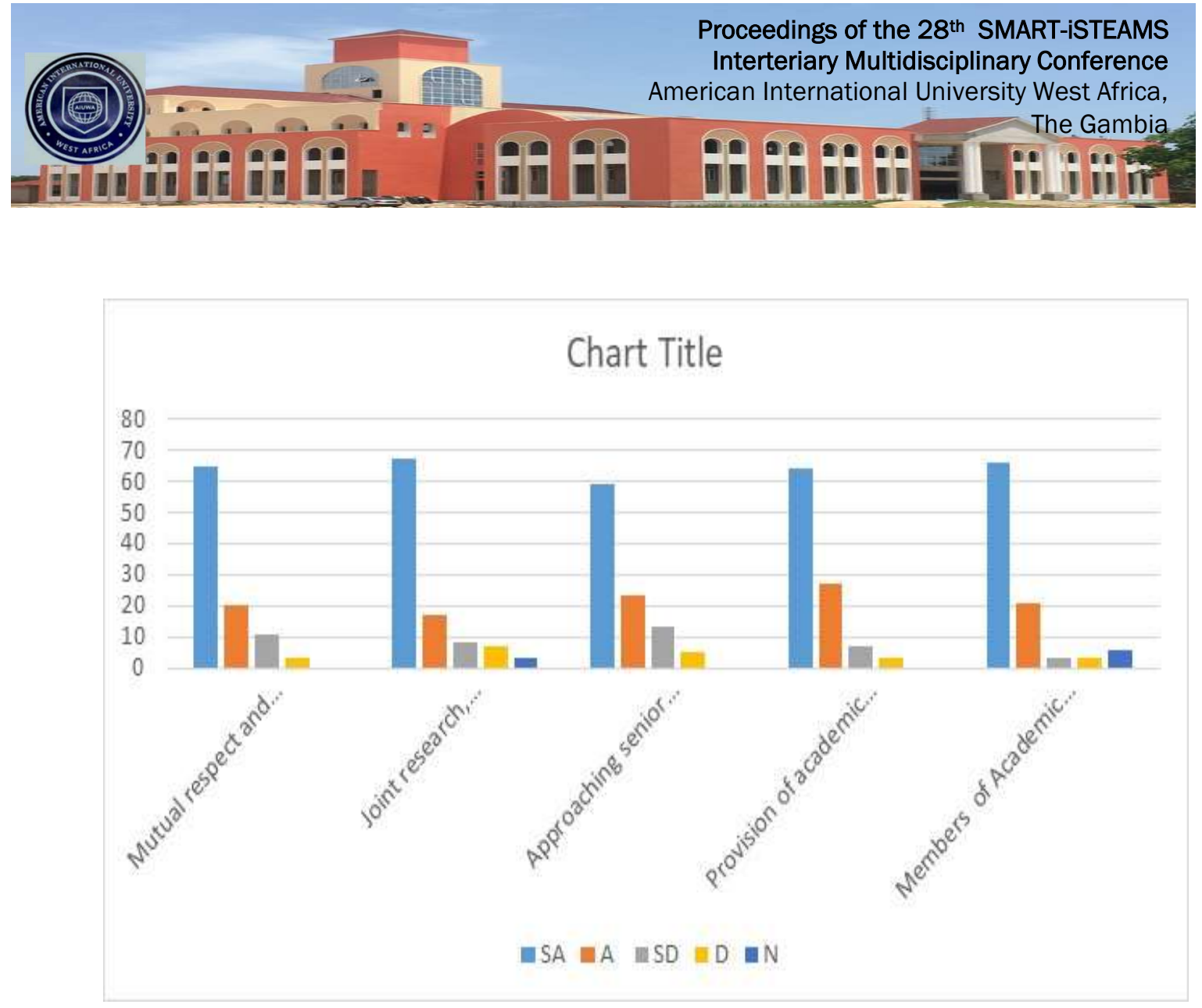

Testing Hypothesis Ho: Academic mentoring is not a determining factor to achieving academic competence in Lagos State Polytechnic, Ikorodu

Decision Rule: According to table below, since the chi-squares calculated (X2-cal) are greater than chi-square tabulated (X2-tab) which makes all the figures to be highly statistically significant with the probability of $\mathrm{F}=0.000$. Collectively, we reject null hypotheses stated earlier that Academic mentoring is not a determining factor to achieving academic competence in Lagos State Polytechnic, Ikorodu we therefore accept alternative hypothesis that: Academic mentoring is a determining factor to achieving academic competence in Lagos State Polytechnic, Ikorodu 


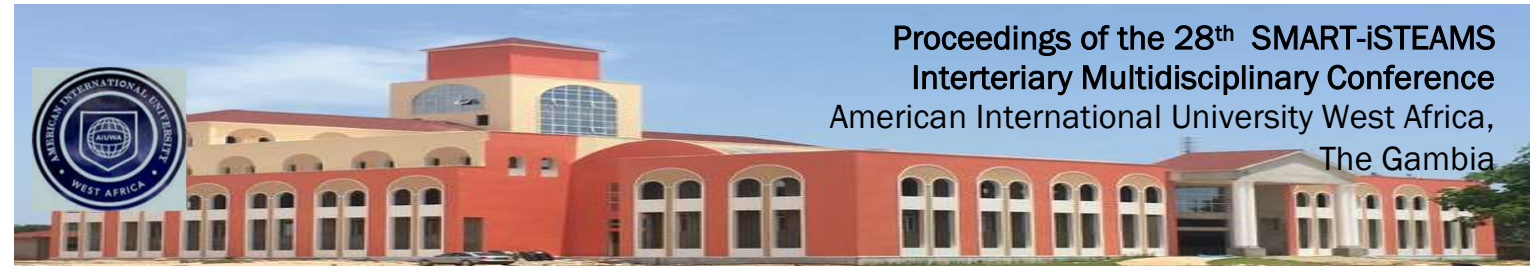

Relationship between Academic mentoring and Academic Competence in Ikorodu Lagos State Polytechnic, Ikorodu Using Chi-Square Analysis Model Summary

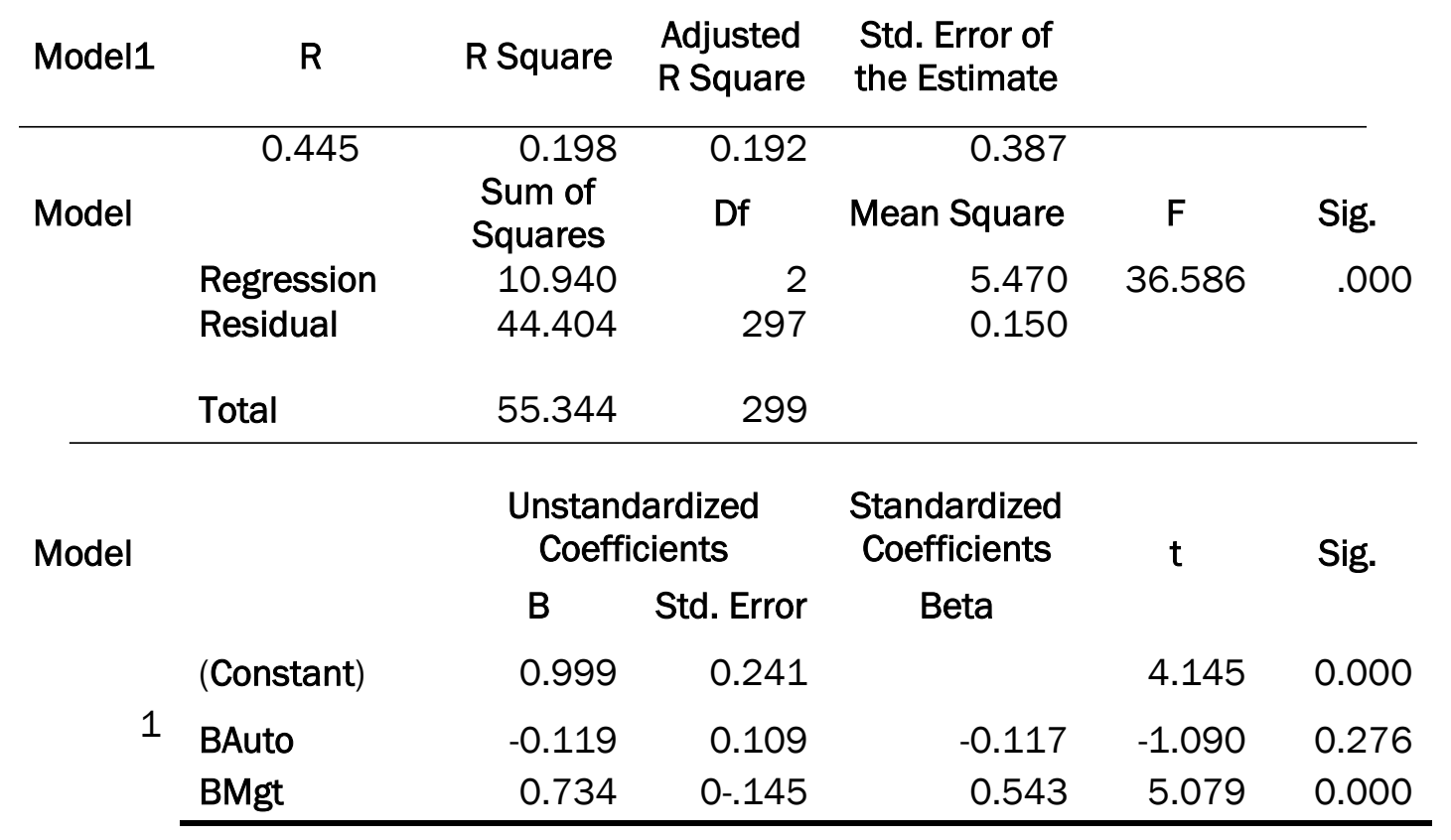

Source: Computations and Out-Put of SPSS based on Author's Field Survey (2021)

\section{CONCLUSION AND RECOMMENDATIONS}

Academic mentoring is an adjudged determining factor in improving academic competence among the teaching staff. This is the practice worldwide, hence should be entrenched among senior and junior academic staff. The practice has many benefits to the mentors, mentees, the organisations and the students; being the final products (graduates) will be able to meet the challenges, world standards and compete favourably with their counter parts.

For career development and good performance, the act of grooming and mentoring the junior and inexperienced ones is essential in every organization. The need for the senior and experienced ones to groom and grow the junior academic staff is more pronounced nowadays than before because the standards of education system is declining especially in this part of the world. To raise the falling academic standard and for our tertiary institutions to compete favourably with their counterparts in the world the management of the institutions must show concern and give opportunities for professional guidance and development of their teaching staff.

Based on our findings we hereby recommend as follows: 


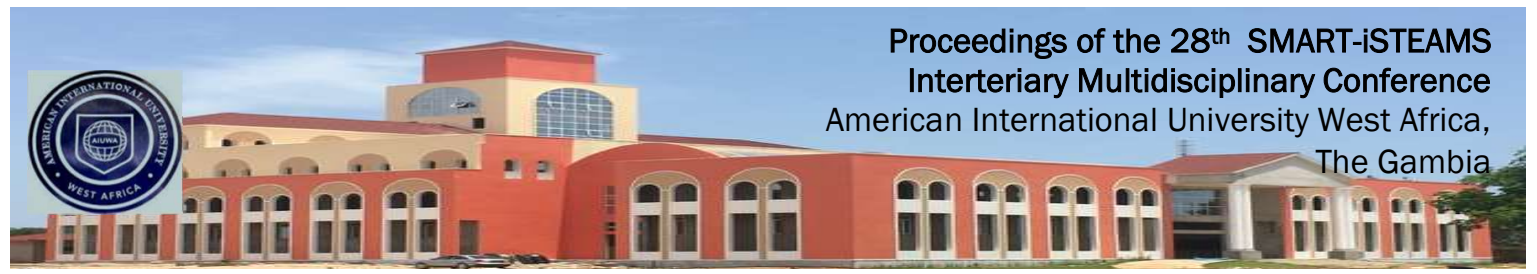

$>$ The management of Lagos State Polytechnic and by extension higher institutions of learning should encourage formal structural relationship between academic mentors and mentees to foster better academic standard in the educational sector.

$>$ In addition to structured relationship an informal academic mentoring and relationship should be allowed to continue and complement the formal structure at all levels of the teaching cadre.

$>$ Newly employed lecturers should always seek advice and guidance from experienced lecturers (Informal mentoring) as to boosts their academic development.

$>$ Experienced Academic Staff should always be ready to guide the less experienced ones in academic related issues. 


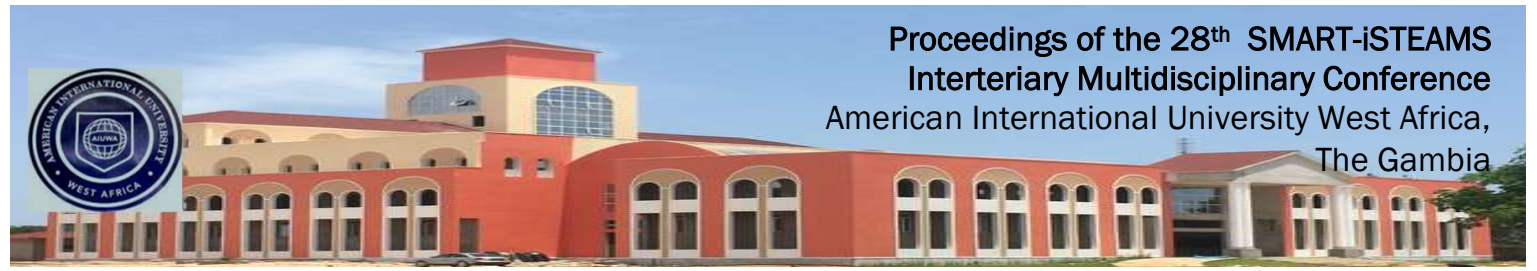

\section{REFERENCE}

1. Abiddin, N.Z. \& Hassan, A. (2012). A review of effective mentoring practices for mentees' development. Journal of Studies in Education, 2(1): 72-89.

2. Abugre, J. B., \& Kpinpuo, S. D. (2017). Determinants of Academic Mentoring in Higher Education: Evidence from a Research University. Educational Process: International Journal, 6(2), 20-36.

3. Archer, L. (2008). Younger academics' constructions of 'authenticity', 'success' and professional identity. Studies in Higher Education, 33(4), 385-403.

4. Bouwma-Gearhart, J. (2012). Research university STEM faculty members' motivation to engage in teaching professional development: Building the choir through an appeal to extrinsic motivation and ego. Journal of Science Education and Technology, 21(5), 558-570.

5. Bozeman, B., \& Feeney, M. K. (2007). Toward a useful theory of mentoring: Conceptual Analysis and Critique. Administrative and Society, 39(6), 719-739.

6. Clutterbuck, D. (2004) Everyone Needs a Mentor, 4thedn. London: chartered institute of personnel and development

7. Cullingford C (2016). Mentoring in education: An international perspective. Abingdon, Oxfordshire. Taylor and Francis.

8. Fischer, Dietlind \& Andel, Lydia van (2002). Mentoring in Teacher Education towards innovative school development Paper presented at the 27th annual conference of ATEE September in Warsaw/ Poland

9. Kirigha, K.A. \& Neema-Abboki, P. (2010). Developing a web Explicit Research Strategy Theory in African Universities: A cross-comparison of Specific Regional Efforts through an Analysis of Research Web Pages. (Publication Retrieved June 25, 2014).

10. Koki S (1997). The Role of teacher mentoring in educational reform. Pacific Resources for Education and Learning. Honolulu, Hawai. Retrieved on 29th January 2020 from https://www.nmu.edu/Webb/ArchivedHTML/UPCED/mentoring/docs/Role-mentor.pdf.

11. Kuijpers, M. A. C. T., Schyns, B., \& Sheerens, J. (2006). Career competencies for career success. The Career Development Quarterly, 55(2), 168-178.

12. Landolt, M.L. (2012). Mentoring. Retrieved on 28 November 2012 from http://www.grad.washington.edu/mentoring

13. Langutani M., Masehela*, Memory M, (2017): Journal of Student Affairs in Africa I Volume 5(2) 2017, 163-182 | 2307-6267 | DOI: 10.24085/jsaa.

14. Maringe, F., \& Gibbs, P. (2008). Marketing higher education. Maidenhead: Open University Press.

15. Martin S (2006). The mentoring process in pre-service teacher education. School Organisation 14(3):269-277.

16. Mary D. S., Jung Yun, and Brian B. (2016): Mutual Mentoring Guide: The Institute for Teaching Excellence \& Faculty Development

17. Masehela, L.M. \& Mabika, M. (2017). An Assessment of the Impact of the Mentoring Programme on Student Performance. Journal of Student Affairs in Africa, 5(2), 163-182. DOI: 10.24085/jsaa. v5i2.2707 


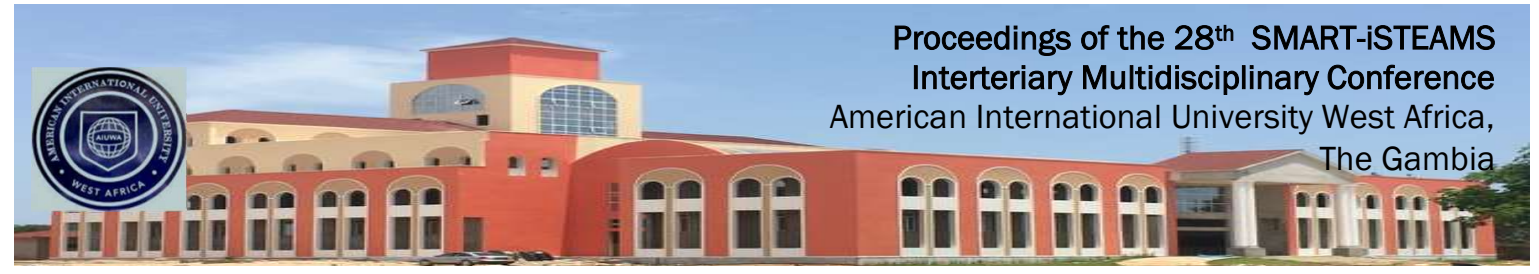

18. Ofobruku, S.A. (2015): Effects of Mentoring on Employees' Performance in Selected Family Business in Abuja, Nigeria. SINGAPOREAN Journal of Business Economics, and Management Studies Vol.4, No. 9

19. Parker, P. M., Authur, B., \& Inkson, K. (2004). Career communities: An exploration of member-defined career structures. Journal of Organizational Behavior, 25(4), 489514.

20. Prakash S.(2013): The Value Of Mentoring To Develop Student Teachers' Work-Integrated Learning Skills. International Business \& Economics Research Journal- Volume 12, Number 11

21. Rebecca LS (2016). Mentoring beginning teachers in primary schools: Research review. Professional Development in Education 43(2):253-273.

22. Rosemary, O. E., Millie N. H. (2015): European Journal of Research and Reflection in Educational Sciences Vol. 3 No. 2, 2015 ISSN 2056-5852

23. Russell, D. (2000). Jumping in a: trust and communication in mentoring student teachers. Teaching and Teacher Education, 16(1), 65-80.

24. Zambrana, R. E., Ray, R., Espino, M. M., Castro, C.,Cohen, B. D., \& Eliason, J. (2015, February). "Don'tleave us behind": The importance of mentoring for underrepresented minority faculty. American Educational Research Journal, 52(1), 40-72. 


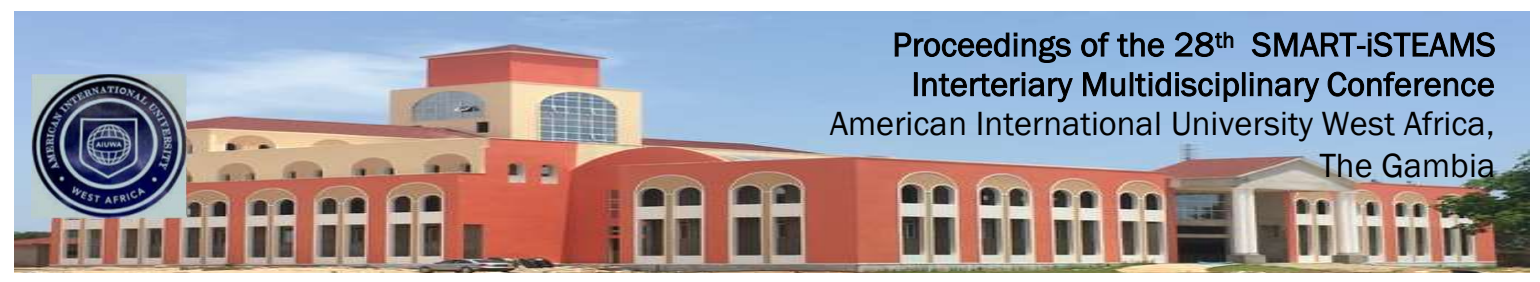

\section{APPENDIX}

Questionnaire on Mentoring as a determinants for academic competence among teaching staff in Lagos State Polytechnic, Ikorodu

\section{Demographic Data}

Male: ( )

Female ( )

Age: $21-30(\quad) \quad 31-40(\quad) \quad 41-50(\quad) \quad 51-60(\quad) 60$ and above ( )

2. Total numbers of Years as an Academic Staff

$1-5$ years 6-10 years 10-15 years 15-20 years 20 years and above $s$

3. Highest level of education:

$\begin{array}{ll}\text { PhD } & (\text { ) } \\ \text { MSc. } & (\text { ) } \\ \text { Bsc. } & (\text { ) } \\ \text { HND } & (\text { ) }\end{array}$

\section{Academic Status}

$\begin{array}{llll}\text { Assistant Lecturer } & ( & & \\ \text { Lecturer III } & ( & & \\ \text { Lecturer II } & ( & & \\ \text { Lecturer I } & ( & & \\ \text { Senior Lecturer } & & & (\quad) \\ \text { Principal Lecturer } & ( & & \\ \text { Chief Lecturer } & ( & \end{array}$

Level of awareness of academic mentoring in Lagos State Polytechnic, Ikorodu

5. Are you aware of mentoring in academics? Yes ( ) No ( )?

6. Are you involve in academic mentoring? Yes ( ) No ( )

7. Do you have a mentor? Yes ( ) No ( )

8. Do you have a mentee? Yes ( ) No ( )

9. Is the relation between you and your mentee/mentor formal

10. Is the relation between you and your mentee/mentor informal 


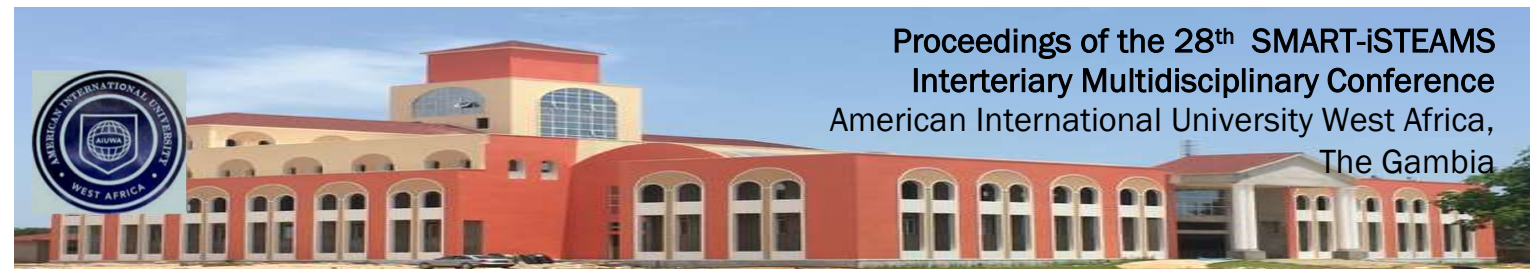

Significant role mentoring play in improving academic competence of mentors and mentee in Lagos State Polytechnic, Ikorodu

11. Mentoring has any positive effect on academic competence?

12. Mentoring improves your academic competence?

13. Mentoring has helped my teaching ability over the years

14. Mentoring has not improved my lecturing skills over the years

15.I gain experiences from my mentor/mentee over years

How mentoring relationships were formed among senior and junior academics

16. Mutual respect and reverence for academic accomplishments, lead to share resources and experience Agreed ( )

17. Joint research, publications, teaching and conference/workshop attendance lead to mentee mentor relationship

18. Approaching senior colleagues with development problems encourages mentoring in academic

19. Provision of academic leadership by senior members lead to mentoring relationships

20. Members of academics can make a request to be mentor or mentee 